\title{
Perbedaan Gender dalam Peran Konflik, Emosional Kerja, dan Kinerja Pegawai Marketing Perusahaan Farmasi di Jawa Tengah
}

\author{
Naning Kristiyana \\ Manajemen, Universitas Muhammadiyah Ponorogo, Indonesia \\ Korespondensi penulis: nrafakristi@gmail.com
}

\begin{abstract}
Marketing employees as the heart of the company have a duty to achieve good performance, work targets must be fulfilled in an effort to contribute to the company's performance. Gender differences in the domestic role of families with work and emotional differences in gender can provide benefits in the recruitment process and the job description of marketing employees. This study aims to determine differences between female employees and male employees in the role of work conflict and to know the differences between female employees and male employees in emotional work and performance as marketing employees of pharmaceutical companies. The sample of all marketing staffs of Takeda Indonesia Pharmaceutical Company in Central Java is 16 people. Primary data collection was done by a questionnaire. This research uses a quantitative descriptive method. The analysis of data uses an ANOVA analysis. The analysis of variance (ANOVA) is used because there are two independent variables with combinations scales, namely interval and nominal (gender), while the dependent variable is interval scale. The results of this research showed that the roles of conflict and performance have no differences between male employees and female employees. For emotional intelligence, there are differences between male employees and female employees. The significant differences mean that there are a real differences between male employees and female employees in their emotional intelligence. Self-control and self-motivation as a form of emotional intelligence showed differences between male marketing employees and female marketing employees.
\end{abstract}

Keywords: Gender, Conflict role, Emotional intelligence, Performance.

\begin{abstract}
Abstrak: Pegawai marketing sebagai jantung perusahaan memiliki beban tugas untuk mencapai kinerja dengan baik, maka target kerja harus terpenuhi dalam upaya memberikan kontribusi pada kinerja perusahaan. Perbedaan gender dalam peran domestik keluarga dengan pekerjaan dan perbedaan emosional pada gender dapat memberikan manfaat dalam proses rekrutmen dan job description pegawai marketing. Penelitian ini bertujuan mengetahui perbedaan pegawai wanita dan pegawai pria dalam peran konflik kerja dan mengetahui perbedaan pegawai wanita dan pegawai pria dalam emosional kerja dan kinerjanya sebagai pegawai marketing perusahaan farmasi di Jawa Tengah. Sampel penelitian adalah seluruh pegawai marketing Perusahaan Farmasi Takeda Indonesia untuk area Jawa Tengah sejumlah 16 orang. Pengumpulan data primer dilakukan menggunakan kuesioner. Penelitian ini menggunakan pendekatan diskriptif kuantitatif.
\end{abstract}


Analisis data pada penelitian ini menggunakan analisis ANOVA (analysis of variance) karena penggunaan dua variabel dengan kombinasi skala pengukuran, yaitu satu variabel diukur dengan skala interval dan yang lain menggunakan skala nominal, sedangkan variabel dependen diukur menggunakan skala pengukuran interval. Hasil temuan dalam penelitian ini menunjukan bahwa peran konflik dan kinerja tidak ditemukan adanya perbedaan antara pegawai pria dan pegawai wanita, sedangkan pada kecerdasan emosional terdapat perbedaan antara keduanya. Perbedaan secara signifikan menunjukkan adanya perbedaan riil pegawai pria dan pegawai wanita dalam kecerdasan emosionalnya. Pengendalian dan motivasi diri sebagai bentuk kecerdasan emosional ditemukan berbeda antara pegawai marketing pria dan wanita.

Article Info:

Received: August 9, $2018 \quad$ Accepted: October 10, 2018

Available Online: December 12, 2018

DOI: http://dx.doi.org/10.30588/jmp.v8i1.378

\section{LATAR BELAKANG}

Perusahaan farmasi merupakan perusahaan yang memiliki fungsi membantu masyarakat dalam mengobati penyakit melalui dokter atau tenaga paramedis lainnya. Seperti halnya di Indonesia sebagai negara berkembang, perusahaan farmasi memiliki potensi dan peluang besar untuk mengembangkan usahanya, sehingga motif profit dapat tercapai. Peluang ini segera dimanfaatkan oleh perusahaan farmasi baik perusahaan nasional maupun perusahaan PMA (Penanaman Modal Asing). Secara makro, semakin banyak perusahaan yang dapat mengembangkan usahanya di Indonesia, semakin baik bagi pertumbuhan ekonomi nasional karena dapat menciptakan lapangan pekerjaan, meningkatkan pendapatan masyarakat, serta pendapatan pajak bagi pemerintah. Bagi perusahaan farmasi yang ada di Indonesia, semakin tinggi persaingan usaha, perusahaan harus mempunyai strategi pemasaran produk untuk memenangkan persaingan.

Tenaga marketing merupakan sumber daya manusia perusahaan yang memiliki peran penting dalam memasarkan produk yang memiliki tugas dan tanggung jawab besar untuk mencapai tujuan perusahaan. Perusahaan harus tanggap untuk mengelola pegawainya agar mampu mencapai kinerja yang diharapkan perusahaan. Perkembangan dunia kerja menuntut gaya hidup dan tuntutan karier, sehingga pegawai marketing tidak hanya dari kaum pria, tetapi juga kaum wanita. Pegawai wanita yang berstatus telah menikah akan memiliki peran berbeda pada pekerjaan dan peran dalam keluarganya. Bagi pria, peran pegawai marketing dan kepala keluarga, sedangkan bagi wanita mereka berperan sebagai pegawai marketing dan ibu rumah tangga.

Menurut Antoniou dkk. (2006), peran yang dilakukan pegawai pria maupun wanita tersebut secara tidak langsung akan rentan memicu konflik peran. Konflik ini jika berlanjut akan menimbulkan dampak negatif pada kinerja mereka sebagai pegawai. Carnicer et al. (2004) mendefinisikan konflik peran sebagai kejadian simultan dari dua atau lebih bentuk tekanan pada tempat kerja, ketika pemenuhan dari satu peran membuat pemenuhan terhadap peran lainnya lebih sulit. Hal ini menunjukkan bahwa ketika seseorang melaksanakan satu peran tertentu dan mengalami kesulitan, maka akan menyulitkannya memenuhi harapan pada peran yang lain, karena terjadi konflik peran. Ketika tuntutan pekerjaan dan tuntutan peran sosial sebagai sebuah tanggung jawab yang harus dilakukan, maka konflik ini cenderung akan makin berkembang. 
Pegawai pria yang berperan sebagai kepala keluarga dan pegawai wanita yang berperan sebagai ibu rumah tangga membuat mereka kesulitan untuk menjalankan semua peran tersebut dengan takaran yang sama. Hal ini menunjukkan bahwa kinerja yang dihasilkan dan dijalankan oleh satu peran dapat berakibat mengabaikan pencapaian kinerja pada peran yang lain. Hal ini dapat mengakibatkan kinerjanya menjadi turun. Apabila hal ini diabaikan akan berpengaruh pada tuntutan target secara keseluruhan. Peran ganda yang berbeda pada saat dijalankan dari setiap pegawai secara langsung menjadikan kondisi ini dapat memicu beban kerja terkait peran yang dilakukan karena pegawai merasa tidak cukup waktunya untuk mampu menghasilkan kinerja secara maksimal untuk semua peran. Menurut Bhanugopan dan Fish (2006), beban peran digolongkan dua pengertian, yaitu beban kualitatif dan kuantitatif. Beban peran kualitatif terjadi, ketika seseorang merasa keahlian yang dimiliki tidak memenuhi tuntutan tugas. Selanjutnya, ketika seseorang kesulitan menyelesaikan tugas dengan waktu yang telah ditetapkan, maka ini disebut sebagai beban peran kuantitatif.

Penelitian yang dilakukan oleh Rahayuningsih dan Sholikhan (2015) terhadap guru SMP (Sekolah Menengah Pertama) di Malang yang diasumsikan sebagai sosok pegawai yang memberikan pelayanan kepada muridnya. Dalam penelitian tersebut, konflik peran dan kelelahan emosional memiliki pengaruh tidak langsung terhadap komitmen organisasi. Hal ini sejalan dengan penelitian yang dilakukan Babakus (1999) yang menyatakan bahwa pekerja dengan tingkat emosional yang tinggi akan merasa kurang puas dengan pekerjaannya dan berakibat kurang perhatian terhadap organisasinya. Burnout atau stres yang tinggi dapat mengakibatkan dampak negatif kualitas kerja pegawai. Bahkan, hal itu dapat menyebabkan pegawai resign dari pekerjaannya, turnover, absen, dan produktivitas kerja yang rendah. Burnout juga berdampak negatif pada individu pegawai, antara lain: motivasi kerja rendah dan bahkan hilang, perasaan gagal, dan depresi, sehingga berakibat juga pada organisasi, seperti tingkat absensi, turnover, dan produktivitas kerja rendah.

Penelitian ini lebih menfokuskan pada pegawai marketing sebagai responden. Pegawai marketing pada perusahaan pemerintah maupun swasta merupakan tonggak tercapainya kinerja perusahaan, baik itu perusahaan jasa maupun barang. Penelitian yang memfokuskan pada tercapainya kinerja sumber daya manusia (SDM) yang tinggi dengan berbagai variabel produktivitas sangat banyak, tetapi penelitian terhadap treatment SDM dan psikologi gender masih sedikit, sehingga peneliti sangat tertarik untuk meneliti perbedaan gender dalam melakukan treatment pegawai, sehingga tujuan perusahaan akan tercapai.

Demikian pula halnya, setiap pegawai marketing akan mencurahkan tenaga secara fisik dan mental, apabila mereka mencurahkan kemampuan tenaga fisik dan kognitif mereka masing-masing ke dalam pekerjaan mereka. Pekerjaan marketing menuntut pegawai secara emosional. Hal ini diekspresikan ketika pegawai menghadapi tuntutan target kerja yang ditetapkan perusahaan kepada sales atau pun pembeli produk farmasi, yaitu dokter, paramedis, apotik, agen obat, dan lain-lain. Pekerjaan jasa sebagai pegawai marketing membutuhkan sopan santun, kemenarikan, keceriaan, dan komunikatif dalam berinteraksi dengan sales. Ketika target kerja pegawai marketing yang ditetapkan perusahaan akan memberikan rangsangan yang memprovokasi emosi pegawai, mereka akan mengekspresikan emosi secara bervarisi tergantung kepribadian individu. 
Beberapa wanita memiliki persepsi lebih emosional dalam mengekspresikan kemampuannya dibandingkan pria. Dari jabatan sebagai marketing, perbedaan pria dan wanita mmemberikan kontribusi dalam kemampuannya secara fisik maupun emosional untuk menghasilkan kinerja yang terbaik untuk keluarganya dan untuk perusahaan. Manajemen sumber daya manusia dapat mengelola emosi dan peran pegawai marketing agar dapat menghasilkan kinerja yang diharapkan. Pengetahuan atas perbedaan pria dan wanita dalam konflik peran dan emosional kerja dapat digunakan sebagai dasar dalam pemberian motivasi, sehingga peran dan emosional kerja dapat mendukung tercapainya tujuan dan target perusahaan. Penelitian ini bertujuan untuk mengetahui perbedaan antara pegawai pria dan pegawai wanita dalam peran konflik kerja, emosional kerja, dan kinerja mereka sebagai pegawai marketing.

\section{KAJIAN TEORITIS}

\section{Konflik Peran}

Konflik peran merupakan konflik yang timbul ketika seorang pegawai melakukan peran yang tidak dikehendaki, maka hal itu dapat memunculkan konflik peran. Menurut Gibson et al. (2006), konflik peran terdiri atas tiga macam, yaitu: (1) konflik peran yang terjadi ketika peran yang dibutuhkan bertentangan dengan nilai dasar, sikap, dan kebutuhan individu pada posisinya; (2) konflik intrarole yang terjadi ketika pegawai dihadapkan pada harapan yang berbeda, menjadikan pegawai tidak memungkinkan untuk memaksimalkan semuanya; dan (3) konflik interrole yang terjadi ketika pegawai menghasilkan berbagai peran secara bersama-sama. Konflik peran terjadi karena hasil yang tidak sesuai dari harapan yang dikomunikasikan kepada pegawai terkait peran yang diberikan oleh atasan (Bhanugopan \& Fish, 2006). Konflik peran lebih jelas disampaikan oleh Koustelios et al. (2004) yang menyebutkan bahwa konflik tersebut dapat terjadi ketika seseorang harus berinteraksi dan mengalami pertentangan perilaku individu yang diharapkan, sehingga terjadi konflik peran pada saat individu melaksanakan satu peran tertentu yang membuatnya mengalami kesulitan untuk memenuhi harapan peran yang lain.

\section{Beban Peran}

Beban peran memiliki dua definisi, yaitu beban kualitatif dan kuantitatif. Ketika seseorang merasa keahlian yang dimiliki tidak memenuhi tuntutan tugas yang dibebankan, maka ia mengalami beban peran kualitatif, sedangkan beban peran kuantitatif terjadi ketika seseorang mengalami kesulitan menyelesaikan tugas dengan waktu yang telah ditetapkan (Bhanugopan \& Fish, 2006). Beban peran kuantitatif merupakan konflik antara tuntutan organisasi dan waktu yang dialokasikan kepada seseorang untuk memenuhinya (Bacharach et al., 1991). Beban peran adalah perbandingan antara banyaknya tugas peran dan waktu yang tersedia untuk memenuhinya, Di sisi lain, beban peran merupakan anteseden time-based dan strainbased bagi konflik pekerjaan-keluarga (Virick et al., 2007). Argumen anteseden timebased berdasarkan dugaan semakin banyaknya target yang harus dicapai pada waktu singkat. Dari perspektif strain-based, beban peran dipandang sebagai penyebab tingginya kelelahan fisik dan psikologis (Virick et al., 2007). 


\section{Konflik Pekerjaan-Keluarga}

Konflik pekerjaan dan keluarga terjadi karena adanya benturan antara tanggung jawab pekerjaan dengan tanggung jawab tugas di rumah atau kehidupan rumah tangga. Konflik pekerjaan dan keluarga terjadi ketika seseorang menjalankan berbagai peran komitmen sebagai pekerja, pasangan dalam rumah tangga, dan orang tua (Frone et al., 1992). Ada tiga proses pendekatan interaksi peran antara pekerjaan dan keluarga, yaitu:

1. Spillover. Spillover terjadi apabila hubungan pekerjaan dan keluarga saling tumpang tindih dengan yang lain. Spillover dapat menjadi positif maupun negatif. Spillover positif terjadi apabila kepuasan dan stimulasi kerja menjadi energi dan kepuasan yang tinggi di rumah, sedangkan spillover negatif terjadi apabila masalah dan konflik di dalam pekerjaan menyebabkan seseorang merasa sulit memberikan partisipasi yang cukup di dalam keluarganya (Duxbury \& Higgins, 1994 dalam Noor, 2004).

2. Kompensasi. Teori kompensasi menyatakan bahwa hubungan antara pekerjaankeluarga adalah negatif, artinya keterlibatan yang tinggi di satu sisi akan mengakibatkan keterlibatan rendah di sisi yang lain.

3. Segmentasi. Teori segmentasi menyatakan bahwa pekerjaan dan keluarga merupakan dua sisi terpisah, sehingga seseorang dapat menjaga sikap, emosi, dan perilaku di dalam pekerjaan mereka secara terpisah dengan kehidupan keluarganya.

\section{Jenis-jenis Konflik Peran}

Manusia sebagai makhluk individu dan makhluk sosial juga dapat mengalami konflik peran kapan pun dan di mana pun. Ada banyak bentuk dan ragam jenis konflik, tetapi Tjosvold (2006) secara garis besar membedakan dalam dua jenis, yaitu konflik internal dan konflik ekternal. Konflik internal berkaitan dengan apa yang diyakini, prinsip-prinsip, atau pegangan hidup individu itu sendiri. Konflik eksternal terjadi saat berhubungan dengan orang lain dan lingkungannya. Konflik ini terjadi apabila ada ketidaksesuaian antara individu dengan orang lain atau lingkungannya. Hal tersebut sesuai dengan pendapat Stoner dan Freeman (1994) dalam Agung (2006) yang menyatakan bahwa manusia sebagai makhluk hidup dan makhluk sosial seringkali mengalami konflik personal, konflik interpersonal, dan konflik antara kelompok dalam kehidupannya.

Konflik personal berkaitan dengan diri pribadi individu terhadap keyakinan dan prinsipnya. Konflik interpersonal dialami ketika terjadi pertentangan antara seseorang dengan orang lain. Konflik antarkelompok muncul apabila terjadi pertentangan antara satu kelompok dengan kelompok yang lain. Dari berbagai macam konflik tersebut di atas, penelitian ini fokus hanya pada konflik interpersonal. Konflik interpersonal dipahami sebagai suatu pertentangan antara satu individu dengan individu lainnya. Konflik interpersonal sebagai suatu masalah serius yang dapat dihadapi semua orang, karena konflik tersebut dapat berpengaruh cukup mendalam terhadap emosi seseorang (Shantz \& Hartup, 1993 dalam Agung, 2006). Hal ini memerlukan perilaku untuk menjaga selfimage dan harga diri dari kerugian yang diakibatkannya. Apabila prinsip konsep diri seseorang pudar, gangguan yang cukup serius akan terjadi dan hubungan dengan orang tersebut akan memburuk. Dua orang akan menjadi saling berselisih karena temperamen yang berbeda. Dalam hal ini, konflik menjadi berkembang karena rusaknya hubungan komunikasi dan adanya perbedaan persepsi. 


\section{Kecerdasan Emosional}

Kajian dan perhatian terhadap pembangunan sumber daya yang berkualitas menghantarkan kepada kajian yang lebih ditekankan pada faktor-faktor yang menentukan optimalisasi pertumbuhan dan perkembangan manusia. Pada awalnya, pandangan cognitive oriented mewarnai upaya peningkatan kualitas sumber daya manusia. Kajian dan temuan yang menunjukkan bahwa keberhasilan seseorang disumbang $20 \%$ dari kecerdasan intelektual dan selebihnya ditentukan oleh kemampuan individu dalam membina hubungan, motivasi diri, dan kemampuan pengendalian emosi. Kemampuan tersebut oleh Solvey disebut kecerdasan emosi (emotional intelligence). Solvey menggolongkan kecerdasan emosional menjadi lima wilayah, yaitu mengenali emosi diri, mengelola emosi, memotivasi diri, mengenali emoasi orang lain, dan seni membina hubungan (Goleman, 2001).

Seseorang memiliki kecerdasan emosi yang meliputi pengendalian diri, semangat, ketekunan, dan kemampuan untuk memotivasi diri sendiri. Kinerja yang tinggi dapat dihasilkan seseorang apabila individu dapat memotivasi diri sendiri. Hal ini dapat berlaku bagi pekerja di semua bidang pekerjaan. Kecerdasan emosi diartikan sebagai kecakapan hasil belajar yang menampilkan hasil kinerja yang menonjol. Menurut Goleman (2001), kecakapan ini meliputi dua macam kemampuan, yaitu: (1) empati merupakan kemampuan individu untuk memahami perasaan orang lain, dan (2) ketrampilan sosial yang merupakan kemampuan mengelola perasaan orang lain dengan baik. Ukuran kecerdasan emosi dapat dilihat dari beberapa aspek. Berikut ini adalah lima kecakapan dasar dalam kecerdasan emosi, yaitu:

\section{Self-awareness (Kesadaran diri)}

Kesadaran diri merupakan kemampuan seseorang untuk mengetahui perasaan dalam diri dan efeknya, serta menggunakannya untuk membuat keputusan bagi diri sendiri, memiliki tolak ukur yang realistis, atau kemampuan diri yang mempunyai kepercayaan diri kuat dan membangkitkannya dengan sumber penyebabnya.

\section{Self-management (Pengaturan diri)}

Pengaturan diri merupakan kemampuan menangani emosinya sendiri, mengekspresikan dan mengendalikan emosi, serta memiliki kepekaan terhadap kata hati, untuk digunakan dalam hubungan dan tindakan sehari-hari.

\section{Motivation (Motivasi)}

Motivasi adalah kemampuan menggunakan hasrat untuk setiap saat membangkitkan semangat dan tenaga untuk mencapai keadaan yang lebih baik, serta mampu mengambil inisiatif dan bertindak secara efektif, serta mampu bertahan menghadapi kegagalan dan frustasi.

\section{Social awareness (Empati)}

Empati merupakan kemampuan merasakan apa yang dirasakan oleh orang lain, mampu memahami perspektif orang lain, mampu menimbulkan hubungan saling percaya, serta mampu menyelaraskan diri dengan berbagai tipe individu.

\section{Relationship management (Ketrampilan sosial)}

Ketrampilan sosial merupakan kemampuan untuk menangani emosi dengan orang lain dan menciptakan serta mempertahankan hubungan dengan orang lain, mampu 
mempengaruhi, memimpin, bermusyawarah, menyelesaikan perselisihan, dan bekerja sama dalam tim.

\section{Kinerja}

Campbell (1996) dalam Mangkunegara (2000:68) mendefinisikan kinerja dalam terminologi perilaku yang relevan dengan tujuan. Menurut Bacal (2001:127), cara terbaik untuk mengevaluasi kinerja adalah dengan menggunakan tujuan, standar, atau pun target. Pencapaian kinerja sebaiknya mencakup penetapan target bagi setiap pegawai. Menurut Bernadin dalam Trihandini (2005), kinerja seseorang dapat diukur berdasarkan enam kriteria dari hasil pekerjaan yang bersangkutan, yaitu:

1. Kualitas merupakan tingkatan yang menunjukan hasil akhir yang dapat dicapai dan mendekati sempurna dalam arti memenuhi tujuan yang diharapkan oleh perusahaan.

2. Kuantitas adalah jumlah yang dihasilkan dan dinyatakan dalam istilah sejumlah unit kerja atau pun merupakan jumlah siklus aktivitas yang dihasilkan.

3. Ketepatan waktu yaitu tingkat aktivitas penyelesaian pekerjaan tersebut pada waktu awal yang diinginkan.

4. Efektivitas merupakan tingkat pengetahuan sumber daya organisasi dengan maksud untuk meningkatkan keuntungan.

5. Kemandirian yaitu karyawan yang dapat melakukan fungsi kerjanya tanpa meminta bantuan dari orang lain.

6. Komitmen yang berarti bahwa karyawan mempunyai tanggung jawab penuh terhadap pekerjaannya.

Suatu sasaran dan proses sistematis untuk mengumpulkan, menganalisis, dan menggunakan informasi untuk menentukan efisiensi dan efektifitas tugas-tugas karyawan, serta pencapaian sasaran merupakan bentuk penilaian kinerja model key performance indicators atau key performance index. Penilaian kinerja menurut pendapat Armstrong (dalam Trihandini, 2005) didasarkan pada pengertian knowledge, skill, expertise, dan behavior yang dibutuhkan seseorang untuk melaksanakan pekerjaan dengan baik dan analisis lebih luas terhadap attributes dan perilaku individu. Keterkaitan antara kinerja dan perilaku peran didukung oleh pendapat Martin (2000) yang menyebutkan bahwa kinerja karyawan tidak dapat hanya dilihat dari kemampuan kerja yang sempurna, tetapi juga kemampuan menguasai dan mengelola diri sendiri, serta kemampuan membina hubungan dengan orang lain. Kecerdasan emosional dan stres kerja akan mempengaruhi kinerja karyawan (Hidayanti dkk., 2008).

Kecerdasan emosional merupakan kemampuan untuk menggunakan emosi secara efektif untuk mencapai tujuan membangun secara produktif dan meraih keberhasilan. Menurut Patton (2000), karyawan dapat meningkatkan kinerjanya, apabila karyawan tersebut dapat menggunakan emosi secara efektif karena ia akan menjadi lebih bertanggung jawab, lebih dapat memusatkan perhatian pada tugas, tidak implusif, dan lebih dapat mengendalikan diri.

\section{Gender}

Secara etimologi, istilah gender berasal dari kata, antara lain: kata latin genus, kata bahasa Inggris pada abad pertengahan gendre, bahasa Yunani gen, dan bahasa Perancis 
genre. Awalnya, secara umum kata tersebut berarti jenis (kata benda) yang menghasilkan (kata kerja), tetapi belakangan secara gramatikal lebih sering digunakan untuk menunjuk jenis kelamin atau sex secara sosial daripada biologis (Tukiran dkk., 2007).

Kaitan antara gender dan seks baru dipersoalkan pada tahun 1968 oleh seorang psikiater bernama Robert Stoller dalam bukunya berjudul Sex and Gender. Dalam buku tersebut, Stoller membahas seseorang yang dilahirkan dengan jenis kelamin (external genetalia) jantan atau betina. Namun, orang tersebut tumbuh berkembang justru lawan jenisnya. Berdasarkan hal inilah, Stoller menggunakan istilah gender untuk menunjuk perilaku, perasaan, pikiran, dan fantasi tentang seks yang tidak selalu berkonotasi secara biologis (Tukiran dkk., 2007). Selanjutnya, Oakley (Tukiran dkk., 2007) mendefinisikan: "gender as a matter of culture that refers to social classification on masculine and feminine," yang dibedakan dengan: "sex that refers to the biological differences between male and female" (Freedman, 2001 dalam Tukiran dkk., 2007). Dengan kata lain, gender yang dimaksud oleh Oakley pada dasarnya merupakan sebuah konstruk sosial. Untuk memahami konsep gender, kata gender harus dibedakan dengan kata seks atau jenis kelamin. Pengertian jenis kelamin merupakan pensifatan atau pembagian dua jenis kelamin manusia yang ditentukan secara biologis yang melekat pada jenis kelaminnya.

Penelitian ini dibatasi menggunakan definisi pada seks atau perbedaan biologis, yakni laki-laki dan wanita. Pembatasan ini dilakukan agar tidak terjadi bias maupun perluasan masalah yang disebabkan oleh definisi gender secara sosial yang mendatangkan arti yang sangat kompleks. Oleh karena itu, penelitian ini hanya menggunakan variabel perbedaan jenis kelamin sebagai definisi gender untuk menguji ada atau tidak adanya perbedaan pada perilaku konflik peran, kecerdasan emosional, dan kinerja pegawai marketing perusahaan farmasi di Jawa Tengah.

Hasil penelitian Rahayuningsih dan Sholikhan (2015) menyebutkan bahwa tidak ada pengaruh langsung dari konflik peran dan kelelahan emosional pada komitmen terhadap organisasi, tetapi keduanya (konflik peran dan kelelahan emosional) memiliki pengaruh tidak langsung terhadap komitmen organisasi. Hasil penelitian Hsieh dan Hsieh (2003) menjelaskan hubungan antara standarisasi pekerjaan dan burnout dengan variabel mediasi role stress (konflik peran dan ambiguitas peran) terhadap tenaga kerja pabrik dan industri jasa di Taiwan. Penelitian tersebut menghasilkan hubungan positif antara role stress dan komponen burnout, kecuali hubungan antara konflik peran dan rendahnya penilaian diri terhadap prestasi kerja. Selain itu, role stress memiliki hubungan yang sangat erat dengan burnout pekerjaan.

Penelitian Bacharach et al. (1991) pada perawat dan insinyur menunjukkan bahwa konflik peran berpengaruh terhadap burnout pada insinyur tetapi hal ini tidak dengan beban peran, tetapi hasil sebaliknya terjadi pada perawat. Konflik peran mempunyai pengaruh negatif yang kuat terhadap kepuasan kerja terhadap perawat atau insinyur. Beban peran mempunyai pengaruh positif yang kuat terhadap kepuasan kerja pada insinyur, tetapi hasil sebaliknya terjadi pada perawat. Penelitian ini juga menemukan tingginya burnout mempengaruhi secara langsung dan kuat terhadap kepuasan kerja pada perawat dan insinyur. Pada riset ini muncul bahwa konflik peran dan beban peran merupakan prediktor kuat pada konflik pekerjaan-keluarga pada insinyur, tetapi pada perawat hanya konflik peran yang berlaku sebagai prediktor. Ditambahkan pula oleh hasil temuan pada riset ini, konflik pekerjaan-keluarga berpengaruh tidak langsung terhadap kepuasan kerja melalui burnout. 


\section{METODE PENELITIAN}

Populasi dalam penelitian ini adalah pegawai marketing perusahaan farmasi PT Takeda Indonesia untuk area Jawa Tengah yang meliputi Semarang, Yogyakarta, dan Surakarta sejumlah 16 orang. Sampel diambil secara keseluruhan berjumlah 16 orang. Data primer dalam penelitian ini diperoleh dengan kuisioner yang diisi oleh responden. Penelitian ini menguji perbedaan jenis kelamin pria dan wanita (gender) terhadap Peran Konflik (Y1), Kecerdasan Emosional (Y2), dan Kinerja (Y3). Variabel peran konflik (Y1) diukur menggunakan indikator: (1) peran dalam keluarga, (2) konflik tekanan, (3) jenis tugas, (4) norma konflik, (5) kepuasan dengan kelompok, (6) kesukaan, (7) bertujuan menetap, dan (8) resolusi konflik. Variabel kecerdasan emosional (Y2) diukur menngunakan indikator: (1) kesadaran diri, (2) pengaturan diri, (3) motivasi, (4) empati, dan (5) ketrampilan sosial. Variabel kinerja (Y3) diukur menggunakan indikator: (1) keahlian teknikal, (2) dedikasi kerja, dan (3) fasilitas interpersonal.

Metode analisis yang digunakan dalam penelitian ini adalah analisis varians (ANOVA) klasifikasi ganda, yaitu analisis varians yang tidak hanya mempunyai satu variabel kelompok, tetapi juga memiliki variabel baris. Untuk menentukan signifikansi harga $\mathrm{F}$ dibandingkan dengan tabel dan taraf signifikansi 5\% atau jika tidak memungkinkan menggunakan signifikansi 1\%. Selanjutnya, penelitian ini menggunakan uji $\mathrm{p}$ (proportion of inference error) atas perbedaan t yang digunakan. Derajat kebebasan uji t adalah $(\mathrm{n} 1+\mathrm{n} 2-2)$, hasil $\mathrm{t}$ tersebut signifikan apabila to $>\mathrm{t}$ tabel. Analisis of varians digunakan untuk menganalisis perbedaan antara jawaban-jawaban pegawai wanita dan pria terhadap peran konflik kerja sebagai pegawai marketing, emosional kerja wanita dan pria sebagai pegawai marketing, dan kinerja wanita dan pria sebagai pegawai marketing PT Takeda Indonesia.

\section{HASIL DAN PEMBAHASAN}

Tugas pegawai marketing antara lain melaksanakan pekerjaan penjualan produkproduk obat dari PT Takeda. Dalam satu bulan tiap tim kerja dan masing-masing pegawai mendapatkan target produk yang harus terjual kepada dokter atau apotik-apotik di wilayah kerja masing-masing. Persaingan bisnis di bidang farmasi membuat kompetisi produk farmasi sangat tinggi, baik bagi pegawai maupun bagi para dokter atau pun apotikapotik. Beban kerja pegawai marketing dalam target penjualan membutuhkan beban emosional dan waktu kerja yang efisien dalam mencapai target, sehingga kinerja pegawai dan tujuan perusahaan dapat tercapai.

\section{Uji Validitas}

Tabel 1. Hasil Uji Validitas Variabel Penelitian

\begin{tabular}{lrr|rrr} 
& $\begin{array}{c}\text { Scale Mean } \\
\text { if Item } \\
\text { Deleted }\end{array}$ & $\begin{array}{c}\text { Scale } \\
\text { Variance if } \\
\text { Item Deleted }\end{array}$ & $\begin{array}{c}\text { Corrected } \\
\text { Item-Total } \\
\text { Correlation }\end{array}$ & $\begin{array}{c}\text { Squared } \\
\text { Multiple } \\
\text { Correlation }\end{array}$ & $\begin{array}{c}\text { Cronbach's } \\
\text { Alpha if Item } \\
\text { Deleted }\end{array}$ \\
\hline Kinerja & 70.44 & 104.263 & .508 & .450 & .643 \\
Kecerdasan emosional & 59.88 & 157.717 & .551 & .490 & .554 \\
Konflik peran & 47.88 & 164.250 & .551 & .490 & .531 \\
Gender & 86.94 & 144.463 & .547 & .425 & .539 \\
\hline
\end{tabular}


Untuk melakukan uji validitas instrumen penelitian, maka hasil olahan data menggunakan SPSS adalah tabel Item-Total Statistics pada kolom Corrected Item-Total Correlation (Tabel 1). Setiap nilai pada kolom ini dibandingkan dengan nilai r pada tabel $\mathrm{r}$ dengan derajat bebas $\mathrm{n}-2$, yaitu $\mathrm{n}$ adalah jumlah responden, sehingga nilai yang digunakan dalam kasus ini adalah tabel $r$ dan diperoleh nilai 0,468. Nilai yang dibandingkan adalah nilai Corrected Item-Total Correlation. Pertanyaan valid adalah yang mempunyai Corrected Item-Total Correlation di atas nilai $\mathrm{r}$ tabel.

Dari tabel Item-Total Statistics pada kolom Corrected Item-Total Correlation di ketahui bahwa nilai pada kolom Corrected Item-Total Correlation berada di atas nilai tabel $r$ atau 0,468 sehingga dapat disimpulkan bahwa data yang diperoleh dalam penelitian ini dinyatakan valid.

\section{Uji Realibilitas}

Uji reliabilitas dimaksudkan untuk menentukan tingkat kepercayaan minimal yang dapat diberikan responden terhadap kesungguhan jawaban yang diterima dari responden. Uji ini juga dimaksudkan untuk mengetahui sejauh mana hasil pengukuran tetap konsisten, apabila suatu alat ukur dipakai dua kali untuk mengukur gejala yang sama dan hasil yang diperoleh relatif konsisten, maka alat ukur tersebut dinyatakan reliable. Instrumen dapat dikatakan andal (reliabel) apabila memiliki koefisien keandalan reliabilitas sebesar 0,6 atau lebih. Alat uji reliabilitas yang digunakan adalah Alpha Cronbach. Apabila angka alpha lebih kecil dari 0,6 maka instruen dinyatakan tidak reliabel dan jika sebaliknya dinyatakan reliabel. Hasil pengujian reliabilitas terhadap semua variabel ditunjukkan Tabel 2 di bawah ini.

Tabel 2. Hasil Uji Reliabilitas Instrumen Penelitian

\begin{tabular}{lcc}
\hline \multicolumn{1}{c}{ Variabel } & Alpha & Keterangan \\
\hline Konflik Peran & 0.9440 & Reliabel \\
Kecerdasan emosional & 0.7939 & Reliabel \\
Kinerja pegawai & 0.7667 & Reliabel \\
\hline Sumber: Data primer diolah & &
\end{tabular}

Sumber: Data primer diolah.

Berdasarkan Tabel 2 di atas, hasil uji reliabilitas menunjukkan bahwa nilai koefisien Alpha Cronbach pada masing-masing variabel memiliki nilai lebih besar dari 0,60 yang berarti seluruh butir pertanyaan dalam variabel penelitian dinyatakan andal, sehingga butir-butir pertanyaan dalam instrumen penelitian ini dapat digunakan untuk penelitian selanjutnya.

\section{Uji Normalitas}

Uji normalitas bertujuan untuk mengetahui apakah data dalam penelitian ini memiliki distribusi normal atau tidak. Statistik parametrik mewajibkan distribusi data normal. Distribusi data normal adalah kemutlakan yang harus dipenuhi. Dalam penelitian ini, uji normalitas yang digunakan adalah uji normalitas Shapiro-Wilk. 
Berdasarkan output test of normality uji normalitas Shapiro-Wilk diperoleh nilai signifikan untuk Gender Pria dan Gender Wanita untuk variabel Kinerja masing-masing sebesar 0,23 untuk pria dan 0,32 untuk wanita. Nilai signifikan Gender Pria dan Gender Wanita untuk variabel Kecerdasan Emosinal masing-masing sebesar 0,26 untuk pria dan 0,86 untuk wanita, sedangkan nilai signifikan Gender Pria dan Gender Wanita untuk variabel Konflik Peran masing-masing sebesar 0,44 untuk pria dan 0,35 untuk wanita. Karena nilai signifikansi Gender Pria dan Gender Wanita untuk ketiga variabel di atas menunjukkan nilai signifikansi yang lebih besar dari 0,05, maka dapat ditarik kesimpulan bahwa data kinerja, kecerdasan emosional, dan konflik peran memiliki distribusi data yang normal.

\section{Uji Contras Test t-Test}

Berdasarkan hasil analisis uji beda dengan menggunakan SPSS diperoleh output independent sample t-test sebagai berikut:

1. Ditemukan nilai signifikansi (sig. 2-tailed) untuk variabel Kinerja sebesar 0,23>0,05, maka sesuai dengan dasar pengambilan keputusan dalam uji independent sample t-test, maka disimpulkan bahwa H0 diterima dan Ha ditolak, yang berarti bahwa tidak terdapat perbedaan Kinerja antara Gender Pria dan Gender Wanita pada lingkup pegawai marketing perusahaan farmasi di Jawa Tengah.

2. Ditemukan nilai signifikansi (sig. 2-tailed) untuk variabel Kecerdasan Emosional sebesar $0,05=0,05$, maka sesuai dengan dasar pengambilan keputusan dalam uji independent sample t-test, maka disimpulkan bahwa $\mathrm{H} 0$ ditolak dan Ha diterima, yang berarti bahwa terdapat perbedaan Kecerdasan Emosional antara Gender Pria dan Gender Wanita pada lingkup pegawai marketing perusahaan farmasi di Jawa Tengah.

3. Ditemukan nilai signifikansi (sig. 2-tailed) untuk variabel Konflik Peran sebesar $0,33>0,05$, maka sesuai dengan dasar pengambilan keputusan dalam uji independent sample t-test, maka disimpulkan bahwa H0 diterima dan Ha ditolak, yang berarti bahwa tidak terdapat perbedaan Konflik Peran bagi Gender Pria dengan Gender Wanita pada lingkup pegawai marketing perusahaan farmasi di Jawa Tengah.

\section{PEMBAHASAN}

\section{Variabel Konflik Peran}

Variabel Peran Konflik menggunakan indikator dari Jehn (1995) yang meliputi konflik berdasarkan konflik keluarga, konflik berdasarkan tekanan, jenis tugas, norma konflik, kepuasan dengan kelompok, kesukaan, bertujuan menetapkan dan resolusi konflik menghasilkan berdasar nilai signifikansi (sig. 2-tailed) untuk variabel konflik peran sebesar 0,33>0,05, maka sesuai dengan dasar pengambilan keputusan dalam uji independent sample t-test, maka disimpulkan tidak terdapat perbedaan konflik peran antara Gender Pria dan Gender Wanita pada lingkup pegawai marketing perusahaan farmasi di Jawa Tengah. Hasil ini berarti bahwa pegawai marketing pria dan pegawai marketing wanita dalam menjalankan tugasnya sebagai peran pegawai marketing tidak terpengaruh terhadap posisi mereka sebagai kepala keluarga bagi pria maupun sebagai peran ibu rumah tangga dalam keluarga bagi pegawai marketing wanita. 
Berdasarkan jawaban responden terbesar dari variabel konflik peran, pegawai marketing pria dan wanita lebih bisa mengendalikan emosi dengan bersikap sabar dan dapat berkomunikasi dengan baik dengan keluarga terhadap permasalahan keluarga, dalam hal ini perilaku pegawai marketing pria dan wanita dapat mengendalikan kondisi kerja dan kondisi keluarga dengan sabar. Hal ini didukung dengan karakteristik reponden dengan usia lebih dari 31 tahun, sehingga pengendalian perilaku dapat dikelola dengan baik, serta masa kerja peagawai yang rata-rata lebih dari 11 tahun. Selanjutnya, dari indikator variabel konflik peran ini, jenis tugas sebagai pegawai marketing, baik pria maupun wanita tidak terganggu dengan aktivitas peran kerja marketing dengan jam kerja lebih dari sembilan jam per hari dalam upaya mengelola waktu untuk urusan keluarga, terutama acara rekreasi keluarga atau kegemaran keluarga lainnya.

\section{Variabel Kecerdasan Emosional}

Variabel kecerdasan emosional dengan nilai signifikansi (sig. 2-tailed) sebesar $0,05=0,05$, maka sesuai dengan dasar pengambilan keputusan dalam uji independent sample T-Test, yang artinya bahwa terdapat perbedaan kecerdasan emosional bagi Gender Pria dengan Gender Wanita pada lingkup pegawai marketing perusahaan farmasi di Jawa Tengah.

Perbedaan secara signifikan berarti ada perbedaan nyata dari pegawai marketing pria dan pegawai marketing wanita dalam kecerdasan emosionalnya. Pengendalian diri dan memotivasi diri sebagai bentuk kecerdasan emosional tampak berbeda antara pegawai marketing pria dan pegawai marketing wanita. Hal ini lebih jelas ditunjukkan dalam jawaban responden untuk memotivasi diri terhadap tugas laporan pekerjaan dengan berkeyakinan dapat menyelesaikan dengan baik, serta dalam target pekerjaan untuk tetap yakin bersemangat ketika terjadi kegagalan dalam target kerja. Perbedaan yang signifikan ini sesuai dengan pendapat Robbins (2003:142) bahwa memang antara wanita dan pria terdapat perbedaan emosi, wanita lebih menunjukkan reaksi emosional dan kemampuan membaca perilaku orang lain. Emosi positif maupun negatif lebih dapat ditunjukkan oleh wanita. Wanita lebih banyak emosi positif saat bekerja dibandingkan pria.

\section{Variabel Kinerja}

Variabel kinerja sebesar 0,23>0,05, maka artinya bahwa tidak terdapat perbedaan kinerja antara Gender Pria dengan Gender Wanita pada lingkup pegawai marketing perusahaan farmasi di Jawa Tengah. Masa kerja pegawai yang lebih banyak lebih dari 10 tahun menunjukkan menguasai suatu pekerjaan sebagai marketing. Sebagai contoh, seorang pegawai marketing yang memiliki masa kerja lama akan lebih berpengalaman dibandingkan dengan seorang pegawai baru. Pegawai lama sudah mampu beradaptasi dengan profesi sebagai marketing, sehingga dari sisi pengalaman kerja pegawai senior akan lebih produktif. Pegawai pria dan pegawai wanita berdasarkan kinerja mereka dalam keahlian teknikal, dedikasi kerja, dan fasilitas interpersonal tidak terdapat perbedaan yang nyata, sehingga kinerja pegawai pria dan wanita tidak ada yang lebih tinggi.

Pegawai pria dan pegawai wanita dalam menjalankan tugasnya sebagai pegawai marketing memiliki persepsi sama dalam menjalankan tugas melalui keahlian teknikal, dedikasi kerja, dan fasilitas interpersonal dalam bentuk berusaha tidak melakukan kesalahan dan berbagi tanggung jawab dengan rekan kerja dalam kelompok atau tim kerja pada perusahaan. Keahlian teknikal dan dedikasi kerja didukung bukti, bahwa pegawai pria dan wanita telah memiliki masa kerja lebih dari 10 tahun, sehingga berdampak pada persepsi kinerja. 


\section{KESIMPULAN DAN SARAN}

Peran konflik mempunyai nilai sebesar 0,33>0,05 dalam uji independent sample T-Test, maka disimpulkan tidak terdapat perbedaan konflik peran antara Gender Pria dan Gender Wanita pada lingkup pegawai marketing perusahaan farmasi di Jawa Tengah. Pegawai pria dan pegawai wanita dalam menjalankan tugasnya sebagai peran pegawai marketing dan peran sebagai kepala keluarga dan ibu rumah tangga memiliki persepsi sama.

Kecerdasan emosional sebesar 0,05=0,05 dalam uji independent sample t-test, yang artinya bahwa terdapat perbedaan kecerdasan emosional antara Gender Pria dan Gender Wanita pada lingkup pegawai marketing perusahaan farmasi di Jawa Tengah. Perbedaan secara signifikan berarti adanya persepsi perbedaan nyata antara pegawai marketing pria dan pegawai marketing wanita dalam kecerdasan emosionalnya. Pengendalian diri dan memotivasi diri sebagai bentuk kecerdasan emosional tampak berbeda antara pegawai marketing pria dan pegawai marketing wanita.

Kinerja pegawai sebesar 0,23>0,05 dalam uji independent sample t-test, maka dapat disimpulkan tidak ada perbedaan kinerja antara pegawai pria dan pegawai wanita pada lingkup pegawai marketing perusahaan farmasi di Jawa Tengah. Pegawai marketing pria dan pegawai marketing wanita dalam menjalankan tugasnya sebagai pegawai marketing memiliki persepsi sama dalam menjalankan tugas melalui keahlian teknikal, dedikasi kerja, dan fasilitas interpersonal pada perusahaan.

Karena tidak ada perbedaan pada peran konflik, maka peneliti memberikan saran untuk menempatkan tenaga marketing tanpa memprioritaskan gender tertentu, karena pegawai marketing wanita ternyata mampu bekerja dan mengelola keluarga dengan baik, dapat bekerjasama dalam kelompok maupun tim kerja. Karena terdapat perbedaan kecerdasan emosional antara pegawai marketing pria dan wanita, maka peneliti menyarankan bahwa untuk menyelesaikan masalah dalam tugas marketing, pimpinan hendaknya dapat memberikan treatment berbeda atas pegawai marketing pria dan wanita. Dalam hal pengendalian diri dan memotivasi dirinya, pegawai marketing wanita lebih tinggi daripada pria. Karena tidak ada perbedaan kinerja antara pegawai marketing pria dan wanita,, maka peneliti memberikan saran untuk menempatkan tenaga marketing tanpa memprioritaskan untuk gender tertentu, karena ternyata pegawai marketing wanita maupun pria sama-sama mampu menghasilkan kinerja yang baik.

\section{DAFTAR REFERENSI}

Agung, H.N. (2006). Pengaruh Konflik Peran Perilaku Anggota Organisasi Terhadap Kinerja Pegawai Pada Kepolisian RI Wilayah Kota Besar Semarang. Tesis.

Antoniou, A.S., Polychroni, F., \& Vlachakis, A.N. (2006). Gender and age differences in occupational stress and professional burnout between primary and high-school teachers in Greece. Journal of Managerial Psychology, Vol. 21 No.7, hal. 682690.

Bacal, R. (2001). Performance Management. Jakarta: Gramedia Pustaka Utama. 
Bacharah, S., Bamberger, P., \& Conley, S. (1991). Work-Home conflict among nurses and engineers: Mediating the impact of role stress on burnout and satisfaction at work. Journal of Organizational Behavior, Vol. 12, hal. 39-53.

Bhanugopan, R. \& Fish, A. (2006). An empirical investigation of job burnout among Expatriates. Personnel Review, Vol. 35 No.4, hal. 449-468.

Carnicer, M.P., Sanches, A.M., \& Perez, M.P. (2004). Work family conflict in a Southern European Country. Journal of Managerial Psychology, Vol. 19 No. 5, hal. 466489.

Bungin, B. (2005). Metodologi Penelitian Kuantitatif. Jakarta: Penerbit Prenada Media.

Chan, D. \& Schmitt, N. (2002). Situational Judgment and Job Performance. Human Performance, 15(3), 233-254.

Fakih, M. (2004). Analisis Gender dan Transformasi Sosial. Yogyakarta: Pustaka Pelajar.

Frone, M.R., Russell, M. \& Cooper, M.L. (1992). Antecedents and outcomes of work family conflict: Testing model of the work family interface. Journal of Applied Psychology, Vol. 2, hal. 300-319.

Gibson, J.L., Ivancevich, J.M., Donnely, J.H., \& Konopaske, R. (2006). Organizations: Behavior, Structure, and Processes. Edisi 12. New Jersey: The McGraw-Hill Companies, Inc.

Goleman, D. (2001). Emotional intelligence untuk mencapai puncak prestasi. Alih Bahasa: Alex Tri K.W. Jakarta: PT. Gramedia Pustaka Utama.

Habel, M.B.P.P. \& Prihastuti (2012). Hubungan antara Kecerdasan Emosional dengan Konflik Peran Ganda pada Guru Wanita di Kota Surabaya. Jurnal Psikologi Pendidikan dan Perkembangan, Vol.1 No. 02, Fakultas Psikologi Universitas Airlangga Surabaya.

Hidayanti, R. et al. (2008). Kecerdasan Emosi, Stres Kerja dan Kinerja Karyawan. Jurnal Psikologi, Vol. 2 No. 1, Surakarta.

Hsieh, Y. \& Hsieh, A. (2003). Does job standardization increase job burnout? International Journal of Manpower, Vol. 24 No. 5, hal. 590-614.

Jehn, K.A. (1995). A Multimethod Examination of The Benefits and Detriments of Intragroup Conflict. Administrative Science Quarterly. In http://findarticles. com/p/articles/mi_m4035.

Koustelios, A., Theodorakis, N., \& Goulimaris, D. (2004). Role ambiguity, role conflict and job satisfaction among physical education teachers in Greece. The International Journal of Educational Management, Vol.18 No. 2, hal. 87-92.

Mangkunegara, A.P. (2000). Manajemen Sumber Daya Manusia Perusahaan. Bandung: Remaja Rosdakarya.

Martin, A.D. (2000). Aplikasi EQ-based Human Resource Management System. Majalah Manajemen, No. 148, Desember.

Noor, N.M. (2004). Work-family conflict, work and family role salience, and women's well being. The Journal of Social Psychology, 144(4), 389-405. 
Noor, N.M. (2010). Pengaruh Kecerdasan Emosional dan Stress Kerja Terhadap Kinerja karyawan (Studi pada Dinas Kebudayaan dan Pariwisata Propinsi Jawa Tengah). Tesis.

Patton, P. (2000). EQ (Kecerdasan Emosional): Landasan untuk Meraih Sukses Pribadi dan Karier. Jakarta: PT Mitra Media.

Rahayuningsih, S. \& Sholikhan (2015). Pengaruh Konflik Peran Kelelahan Emosional Terhadap Komitmen Organisasi pada Guru. Jurnal Pendidikan Bisnis dan Manajemen, Vol. 1 No. 3, Universitas Kanjuruhan Malang.

Robbins, S. (2003). Perilaku Organisasi. Jilid 1. Jakarta: PT Indeks Kelompok Gramedia.

Tjosvold, D. (2006). Defining Conflict and making choices about its management: Lightening the derkside of organizational life. International Journal of Conflict Management, 17(2), 87-95.

Trihandini, R.A.F.M. (2005). Analisis Pengaruh Kecerdasan Intelektual, Kecerdasan Emosi dan Kecerdasan Spiritual terhadap Kinerja Karyawan. Skripsi (tidak diterbitkan), Fakultas Magister Manajemen UNDIP Semarang.

Tukiran, Kutanegara, P.M., Pitoyo, A.J., \& Latief, M.S. (2007). Sumber Daya Manusia dan Tantangan Masa Depan. Yogyakarta: Pustaka Pelajar.

Virick, M., Lilly, J., \& Casper, W. (2007). Doing more with less: An analysis of work life balance among layoff survivors. Journal of Career Development Internati-onal, Vol. 12 No. 5. 